\title{
ДИАГНОСТИКА ПРИРОДНОЙ СРЕДЫ В ЗОНЕ ФУНКЦИОНИРОВАНИЯ ВРЕМЕННОЙ ПЛОЩАДКИ СКЛАДИРОВАНИЯ СНЕГА В МИНСКЕ
}

\author{
В.С. Хомич, Л. А. Кравчук, О. В. Кадацкая, Е. В. Санец, Е.П. Овчарова, \\ В. А. Рыжиков, Н. М. Баженова
}

Институт природопользования Национальной академии наук Беларуси, Республика Беларусь

$$
\text { Поступила в редакичию } 9 \text { марта } 2019 \text { г. }
$$

\begin{abstract}
Аннотация: В статье приводятся результаты изучения компонентов природной среды в районе расположения одной из площадок временного складирования снега (ПСС) в городе Минске, организованной на резервном участке перспективной ландшафтно-рекреационной зоны. Показано, что как источник загрязнения окружающей среды ПСС представляет собой временную техногенную геохимическую аномалию с повышенным содержанием в твердом осадке хлоридов, натрия, нефтепродуктов и тяжелых металлов.
\end{abstract}

Ключевые слова: площадка временного складирования снега, твердый осадок, загрязнение природной среды, трансформация.

\section{Diagnostics of the natural environment in the area of operation of the temporary snow storage site in Minsk}

\section{S. Khomich, L. A. Kravchuk, O. V. Kadatskaya, E. V. Sanets, E. P. Ovcharova, V.A. Ryzhikov, N. M. Bazhenova}

\begin{abstract}
The article presents the results of studying the components of the natural environment in the area of one of the sites of temporary storage of snow (PSS) in Minsk, organized on the stand-by section of a promising landscape and recreational zone. It is shown that as a source of environmental pollution, PSS is a temporary technogenic geochemical anomaly with a high content of chlorides, sodium, petroleum products and heavy metals in solid sediment.
\end{abstract}

Key words: temporary snow storage sites, solid sediment, environmental pollution, environmental pollution, transformation.

\section{ВВЕДЕНИЕ}

Климатические условия Беларуси способствуют формированию снежного покрова на территории страны в зимний период. В среднем отрицательная температура воздуха устанавливается во второй половине ноября и заканчивается во второй половине марта. На этот отрезок времени приходится около $30 \%$ годовой суммы осадков, которые выпадают преимущественно в виде снега.

$\mathrm{C}$ накоплением снега на урбанизированных территориях, связана необходимость их очистки от снежных масс для создания благоприятных условий для функционирования транспортной сети, работы предприятий, организаций и служб города.

(С) Хомич В.С., Кравчук Л. А., Кадацкая О. В., Санец Е. В., Овчарова Е.П., Рыжиков В.А., Баженова Н.М., 2019
Для уборки снега с улиц, дорог, проездов и других городских территорий в Минске используются три способа в зависимости от взаиморасположения дорог различного назначения и городских строений. На открытых территориях с удаленными от проезжей части строениями используется переброска снега на придорожную территорию роторной снегоуборочной техникой, при этом снег разбрасывается в полосе до 10-15 м от дороги. На городских улицах и тротуарах применяется смет и сдвиг к бордюрам плужно-щеточной техникой. В центральной части города и на улицах, к которым близко примыкают здания и тротуары, снег собирается и вывозится на площадки временного складирования снега (ПСС).

Таким образом, очистка территории города от снега предполагает выделение определенных мест 


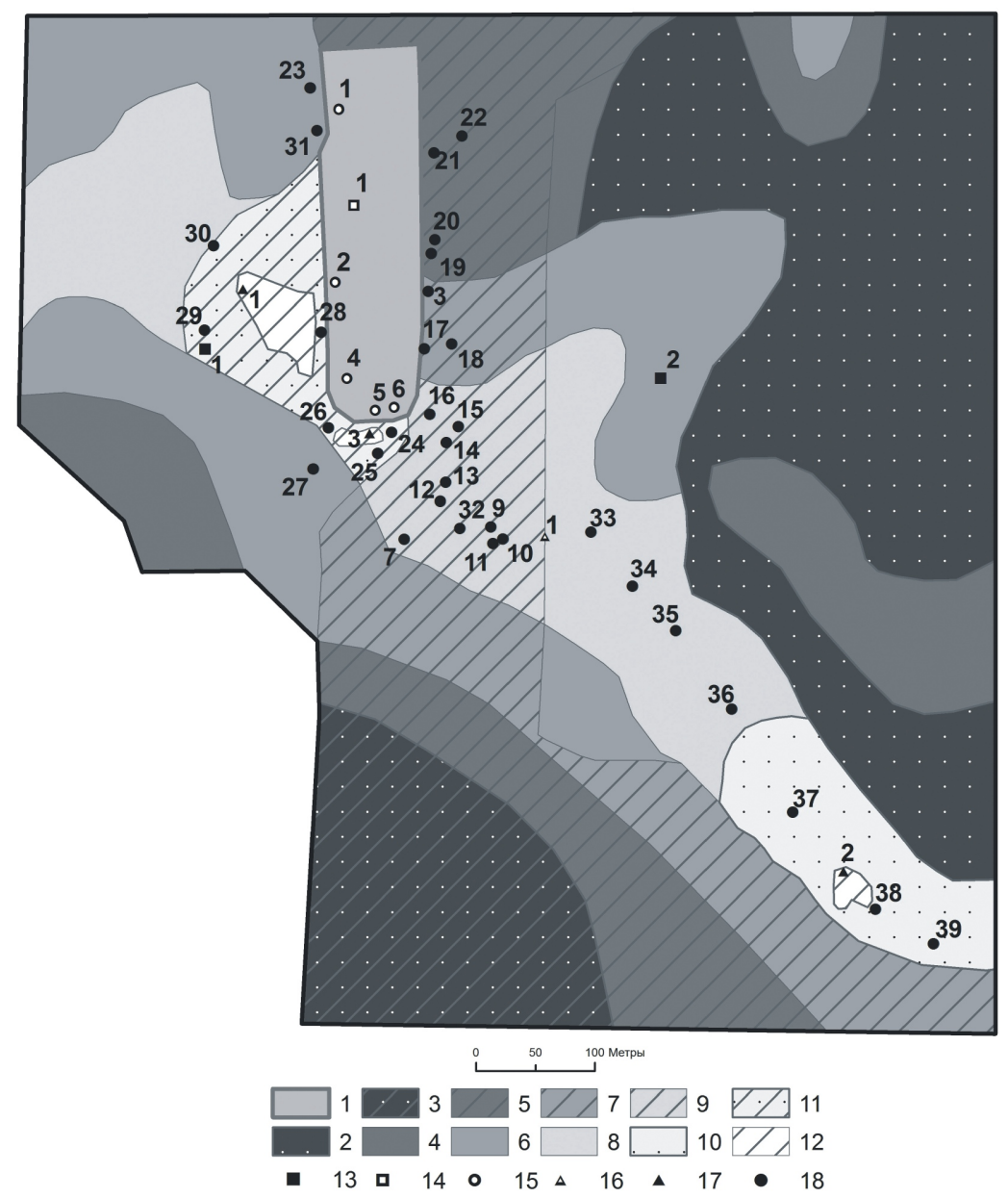

Puc. 1. Картосхема расположения площадки временного складирования снега в структуре сопряженных элементарных ландшафтов и точек отбора проб:

$\mathbf{1}$ - временная площадка складирования снега; $\mathbf{2 . . 1 2}$ - элементарные ландшафты: 2 - элювиальные, 3 - новообразованные элювиальные, 4 - трансэлювиальные, 5 - новообразованные трансэлювиальные, 6 - элювильно-аккумулятивные, 7 - новообразованные элювильно-аккумулятивные, 8 - транссупераквальные, 9 - новообразованные транссупераквальные, 10 - супераквальные, 11 - новообразованные супераквальные, 12 - новообразованные аквальные; $13 . . .18$ - точки отбора проб: 13 - снега естественного залегания, 14 - снега из толщи ПСС; 15 - твердого осадка ПСС после таяния снега; 16 - поверхностного стока талых вод с ПСС, 17 - поверхностных вод; 18 - почв и почвогрунтов.

для его временного складирования, которые располагаются, как правило, в черте города на землях запаса (резервных и прочих территориях). Согласно данным ГПО «Горремавтодор», в зимний период 2016-2017 годов в Минске действовало 16 ПСС, объем складированного снега на которых составил около 286 тыс. м³. В последние годы в Минске для утилизации снега с проезжих частей улиц используется снегоплавильная установка производительностью 5 тыс. м³/сут, однако доля убираемого и растопленного с ее помощью снега (28,6\% зимой 2016-2017 гг.) недостаточна для решения проблемы городских «снеговых свалок».

Снег, убираемый с автомагистралей и улиц города, подвергается загрязнению в первую очередь в результате повсеместного использования противогололедных смесей, основой которых являются песчано-солевые материалы с использованием галитовых отходов калийных производств (ОАО «Беларуськалий», г. Солигорск), состоящих на 95,4\% из $\mathrm{NaCl}$. Кроме того, транспортируемый на ПСС снег подвергается загрязнению за счет движения автотранспорта и механического замусоривания снежного покрова.

Следовательно, снег с территории города попадает на ПСС в достаточной степени загрязненным как химическими веществами, так и примесями разнообразного мусора. К началу снеготаяния складированный снег представляет собой снежно-ледовое образование, которое становит- 
ся источником загрязнения компонентов природной среды.

\section{ОБЪЕКТ ИССЛЕДОВАНИЙ}

Изучение состояния природной среды в зоне функционирования временной площадки складирования снега проводилось на участке общей площадью около 160 га, расположенном в районе ул. Пономаренко в городе Минске. Собственно ПСС была организована в северо-западной части изучаемого участка, который согласно схеме функционального зонирования Генерального плана Минска [3] является резервной территорией ландшафтно-рекреационной зоны, запланированной для создания в ее пределах многофункционального парка с высокими рекреационными нагрузками. Данная территория имеет большую рекреационную значимость - в прилегающей к ней жилой застройке в пределах радиуса доступности для рекреационного обслуживания проживает около 150 тыс. жителей пяти микрорайонов жилой многоквартирной застройки.

Помимо влияния собственно «снеговой свалки», данная территория испытывает многофакторное воздействие со стороны отвалов грунтов метростроя, расположенных к западу от нее, различных нарушений, связанных с земляными работами, а также техногенных объектов на изучаемом участке (теплотрасса, дорога).

ПСС и зона ее воздействия расположены на склонах плоскостного смыва и делювиального накопления. Южная окраина участка, приуроченная к понижению, имеет уклон с севера на юг (относительные превышения до 3 м) и с северо-запада на юго-восток (до 4 м) и находится в ложбине между холмами, что определяет направленность воздействия «снеговой свалки» на местные ландшафты.

С ландшафтно-геохимической точки зрения ПСС занимает элювиально-аккумулятивное положение в системе сопряженных элементарных ландшафтов, связанных между собой миграцией химических веществ. В данном случае распространение загрязняющего воздействия «снежной свалки» возможно проследить с учетом геохимической ориентированности соподчиненных элементарных ландшафтов: транссупераквальных, супераквальных и аквальных, определяющих направление основного потока талых снеговых вод (рис. 1).

\section{МЕТОДИКА ИССЛЕДОВАНИЙ}

Для исследований и оценки состояния ПСС и зоны ее влияния использованы методические под- ходы геохимии городских ландшафтов $[11,14,15]$. Основными методами полевых исследований явились ландшафтно-геохимический и биоценотический. С использованием космоснимков и топокарты М 1:5000 в полевых условиях уточнялось использование территории, изучалась и картировалась нарушенность рельефа, поверхностных отложений и почв территории, описывалось состояние поверхностных вод и растительности.

При исследовании отбирались пробы почв, техногенных отложений (твердого осадка после таяния снега на ПСС), снега в различных условиях (из толщи ПСС и в естественном залегании), талых снеговых вод, формирующих временные водотоки, и вод из водоемов, функционирующих в зоне воздействия (точки опробования рис. 1).

Снег отбирался в конце зимнего периода 20162017 годов собственно на ПСС и в зоне ее влияния. Опробование снежного покрова выполнено в соответствии с [12] с последующим химико-аналитическим исследованием проб согласно [8].

Во время обследования проводился отбор проб воды (талых снеговых, временных водотоков и сформированных водоемов), с последующим определением в них содержания основных макрокомпонентов, биогенных элементов, тяжелых металлов и нефтепродуктов.

Лабораторные методы исследований включали, обработку полевых материалов, подготовку проб, общий гидрохимический и атомно-абсорбционный анализы, извлечение водной вытяжки из почв и техногенных отложений и определение их солевого состава, определение содержания нефтепродуктов флюоресцентным методом.

\section{СОСТОЯНИЕ ПРИРОДНОЙ СРЕДЫ В РАЙОНЕ ИССЛЕДОВАНИЯ}

Состояние природных вод. Опробование снежного покрова в районе расположения свалки показало, что на данной территории атмосферные осадки в зимний период характеризуются высоким содержанием гидрокарбонатов (в среднем 9,2 мг/дм $\left.{ }^{3}\right)$, аммонийного азота $\left(0,41\right.$ мг/дм $\left.{ }^{3}\right)$, хлоридов (7,1 мг/дм $\left.{ }^{3}\right)$ и натрия (2,7 мг/дм³) (таблица 1). По классификации О.А. Алекина состав осадков - гидрокарбонатно-хлоридный кальциево-натриевый [1] (гидрокарбонаты - 40,9\%-экв, хлориды - 52,8\%-экв, кальций - 29,5\%-экв, натрий $37,1 \%$-экв). Если гидрокарбонаты и аммонийный азот являются типичными примесями, характерными для загрязненной атмосферы городов, то наличие хлоридов и натрия в столь высоких для 
Химический состав различных типов вод в районе расположения снеговой свалки (средние данные за 2016-2018 гг.), мг/дм³

\begin{tabular}{|c|c|c|c|c|c|c|c|c|c|c|c|c|}
\hline$\stackrel{\pi}{2}$ & $\overbrace{0}^{\infty}$ & $\dot{U}$ & $\stackrel{\sim}{+}^{+}$ & 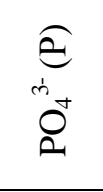 & $\begin{array}{l}\widehat{Z} \\
\hat{O} \\
Z\end{array}$ & $\begin{array}{l}\widehat{Z} \\
\delta^{\prime} \\
Z\end{array}$ & $\begin{array}{l}\widehat{Z} \\
\text { 要 } \\
\text { z }\end{array}$ & さే & $\stackrel{+}{+\infty}_{\Sigma}^{+\infty}$ & ${ }^{+} \pi$ & $\stackrel{+}{ \pm}$ & 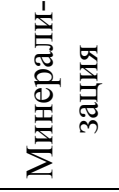 \\
\hline \multicolumn{13}{|c|}{ Снежный покров естественного залегания в районе расположения ПСС (2)* } \\
\hline 6,7 & 9,2 & 7,1 & 1,3 & - & 0,074 & 0,010 & 0,410 & 1,7 & 0,8 & 2,7 & 0,2 & 23,0 \\
\hline \multicolumn{13}{|c|}{ Снег из толщи снеговой свалки (1) } \\
\hline 7,8 & 90,3 & 457,3 & 4,1 & - & 0,029 & 0,079 & 0,000 & 20,8 & 1,5 & 310,0 & 1,5 & 885,5 \\
\hline \multicolumn{13}{|c|}{ Поверхностный сток талых снеговых вод со снеговой свалки (1) } \\
\hline 7,3 & 207,5 & 303,3 & 1,4 & 0,023 & 0,035 & 0,000 & 0,000 & 30,5 & 3,4 & 233,0 & 4,9 & 784,5 \\
\hline \multicolumn{13}{|c|}{ Временный водоем у западного борта снеговой свалки (1) } \\
\hline 7,7 & 137,3 & 643,9 & 2,0 & 0,040 & 0,020 & 0,007 & 0,092 & 29,5 & 3,5 & 467,0 & 4,4 & 1293,5 \\
\hline \multicolumn{13}{|c|}{ Временный водоем у южного борта снеговой свалки (3) } \\
\hline 7,4 & 201,4 & 370,1 & 7,6 & 0,037 & 0,076 & 0,002 & 0,106 & 39,2 & 9,9 & 255,7 & 5,2 & 889,2 \\
\hline \multicolumn{13}{|c|}{ Временный водоем в 500 м к юго-востоку от снеговой свалки (3) } \\
\hline 8,3 & 134,2 & 165,3 & 2,1 & 0,058 & 0,073 & 0,001 & 0,068 & 24,3 & 3,4 & 128,9 & 5,4 & 474,8 \\
\hline \multicolumn{13}{|c|}{ Карьерный водоем на прилегающей территории вне зоны воздействия снеговой свалки } \\
\hline 7,8 & 131,5 & 15,1 & 10,4 & 0,014 & 0,026 & 0,001 & 0,138 & 35,1 & 10,5 & 6,1 & 1,5 & 213,7 \\
\hline \multicolumn{13}{|c|}{ ПДК для водных объектов рыбохозяйственного назначения } \\
\hline $\begin{array}{c}6,5- \\
8,5\end{array}$ & - & 300 & 100 & 0,066 & 9,03 & 0,024 & 0,39 & 180 & 40 & 120 & 500 & 1000 \\
\hline
\end{tabular}

* В скобках номер точки отбора пробы (место отбора показано на рис. 1).

атмосферных осадков концентрациях указывает на наличие локальных источников их аэрального поступления [8]. Одним из таких источников может быть развевание субстрата снеговой свалки сильным ветром и метелевой перенос материала на прилегающую территорию.

Анализ снеговых вод из тела «свалки» ПСС показывает существенные превышения практически по всем показателям макрокомпонентного состава по сравнению с таковыми в снежном покрове на изучаемом участке. В снеге отвала (свалки) регистрируется высокое содержание хлорид-ионов, ионов натрия, кальция, гидрокарбонат-ионов, сульфат-ионов и ионов магния. Сумма ионов в снеговых водах из толщи снеговой свалки в 38,6 раз превышает сумму ионов в снеговых водах на прилегающей территории.

По сравнению с природными водами снеговые воды ПСС обогащены также тяжелыми металлами - свинцом (18,5 мкг/дм $\left.{ }^{3}\right)$, медью (28,3 мкг/дм $\left.{ }^{3}\right)$, цинком (20,1 мкг/дм $\left.{ }^{3}\right)$ и марганцем (55,8 мкг/дм $\left.{ }^{3}\right)$.
Содержание марганца в них превышает фоновые значения в 63,2 раза, меди - в 11,1, свинца - в 7,5, кадмия - в 3,5, никеля - в 3,0 и цинка - в 1,6 раза. Очевидно, что именно этими элементами и будет определяться основная химическая нагрузка со стороны ПСС на прилегающую территорию.

Характерной особенностью гидрографической сети рассматриваемой территории является наличие временных водных объектов в зоне влияния ПСС, которое явилось следствием несоблюдения требований к размещению и эксплуатации подобных объектов [10]. На части площадки складирования снега имеется асфальтобетонное покрытие, однако обвалование по периметру отсутствует. Роль барьера, препятствующего распространению водных потоков и твердых наносов, выполняют инженерные сооружения (теплотрасса, грунтовая дорога), проходящие с севера на юг участка. Каналы для отвода талых вод отсутствуют, однако организован проток талых вод через теплотрассу и грунтовую дорогу (трубы под насыпями). В це- 


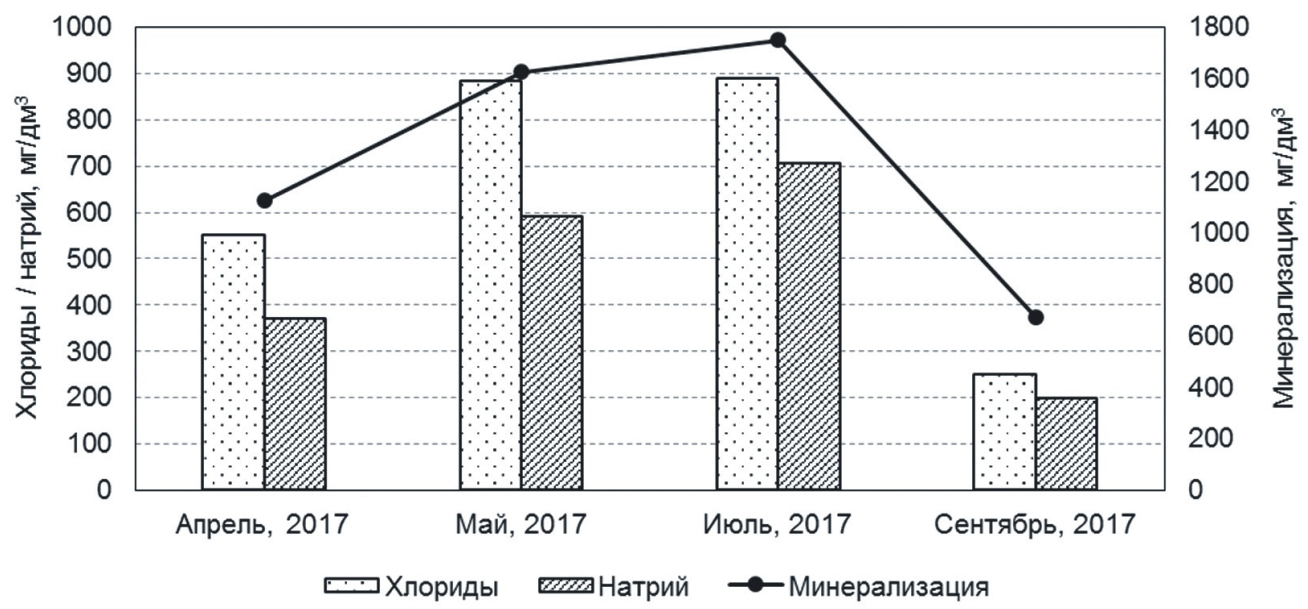

Puc. 2. Внутригодовая динамика общей минерализации, содержания хлоридов и натрия в воде временного водоема у западного борта площадки складирования снега в 2017 году

лом сток проходит по естественным понижениям рельефа с последующей инфильтрацией в почву или застаиванием в замкнутых выемках и котловинах.

Наиболее крупные водоемы, сформированные в основном талыми снеговыми водами, приурочены к западному и южному бортам отвала ПСС, а также к понижению в рельефе в 500 м к юго-востоку по направлению основного потока талых снеговых вод. Обследование территории в различные сезоны 2016-2018 годов показало, что данные водоемы при определенных условиях сохраняются в течение всего года и функционируют как самостоятельные экосистемы, о чем свидетельствует наличие макрофитной растительности и околоводной фауны (земноводные, водоплавающие птицы).

Согласно результатам исследования, наиболее загрязненным оказался временный водоем у западного борта ПСС. Средняя минерализация воды за период наблюдения составила 1293,5 мг/дм ${ }^{3}$ (солоноватые воды), главным образом за счет высоких концентраций хлоридов (643,9 мг/дм³) и натрия (467,0 мг/дм³) - основных компонентов противогололедных смесей и, как следствие, основных загрязняющих веществ в зоне влияния снеговой свалки (таблица 1). Характерно, что высокое содержание данных ингредиентов в воде водоема фиксировалось не только в период снеготаяния, но и на протяжении всего года, уменьшаясь к осеннему сезону (рис. 2).

Концентрации остальных макрокомпонентов и биогенных элементов в воде данного водоема были невысокими и соответствовали значениям, характерным для поверхностных вод бассейна Днепра [5].
По классификации О. А. Алекина вода водоема у западного борта ПСС относится к хлоридному натриевому типу: среднее содержание хлоридов составило $86 \%$-экв, натрия - $90 \%$-экв (рис. 3а). Данный тип вод является азональным для природных условий Беларуси и встречается на территориях, подвергающихся интенсивному техногенному воздействию, - зонах влияния снеговых свалок в городах и местах добычи калийных и каменных солей [2, 13].

Вода временного водоема у южного борта ПСС характеризуется несколько меньшими величинами минерализации $(889,2$ мг/дм³ $)$ и содержания хлоридов и натрия (соответственно 370,1 и 255,6 мг/дм $\left.{ }^{3}\right)$. Тем не менее концентрации указанных элементов превосходят не только величины природно-техногенного геохимического фона [5], но и ПДК для поверхностных водных объектов (300 мг/дм³ для хлоридов, 120 мг/дм ${ }^{3}$ для натрия) [6]. Тип воды водоема - азональный гидрокарбонатно-хлоридный натриевый: доля гидрокарбонатов составила в среднем $40 \%$-экв, хлоридов - 57, натрия - 66\%-экв (рис. 3б).

Ниже по потоку талых снеговых вод, в 500 м к юго-востоку от ПСС вода временного водоема также характеризовалась повышенной минерализацией $\left(474,8\right.$ мг/дм $\left.{ }^{3}\right)$, высоким содержанием хлоридов $\left(165,3\right.$ мг/дм $\left.{ }^{3}\right)$ и натрия $(128,9$ мг/дм³ $)$. Тип воды хлоридно-гидрокарбонатный кальциево-натриевый: доля гидрокарбонатов - $60 \%$-экв, хлоридов - 39, кальция - 36, натрия - 52 \%-экв (рис. 3в).

Анализ проб воды на содержание тяжелых металлов показал высокие концентрации меди и цинка в воде всех временных водоемов, а в воде водоема у южного борта ПСС - также свинца и мар- 

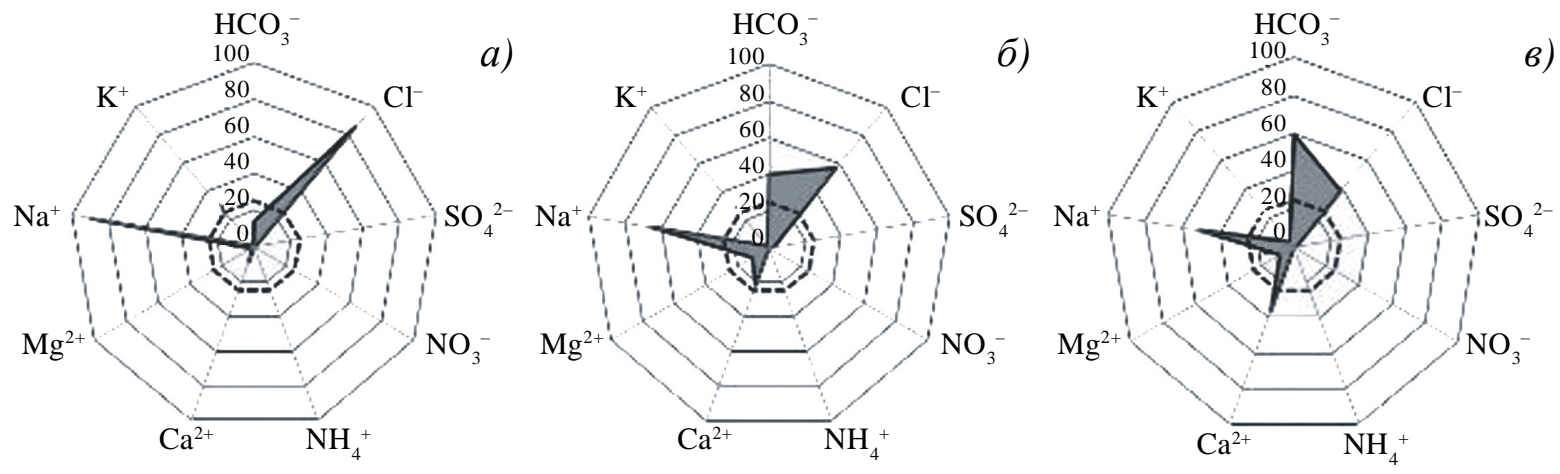

в)

Puc. 3. Ионный состав воды временных водных объектов в зоне функционирования ПСС (усредненные данные за 2016-2018 гг.),\%-экв: а) водоем у западного борта ПСС; б) водоем у южного борта ПСС; в) водоем в 500 м к юго-востоку от ПСС

(пунктирной линией отмечено значение $25 \%$-экв, идентифицирующее тип воды)

ганца. При этом наиболее высокие значения были выявлены в весенние месяцы сразу после окончания периода снеготаяния: содержание меди превышало предельно допустимые значения для поверхностных водных объектов в 3,9-7,6 раза, цинка - в 1,4-6,3, свинца - в 1,8-2,3, марганца - в 15,0 раз. Нефтепродукты в воде временных водоемов были выявлены в концентрациях 0,012$0,034 \mathrm{Mг} /$ дм $^{3}$, что существенно ниже предельно допустимого значения (ПДК - 0,050 мг/дм³).

Обследование территории в направлении уклона поверхности от снеговой свалки не выявило распространения водных потоков далее 500-600 м от нее. Можно предположить, что зона воздействия ПСС на прилегающую территорию в юго-восточном направлении за счет поверхностного стока распространяется именно на это расстояние, а само воздействие проявилось в формировании новых вполне устойчиво функционирующих экосистем (временных водных объектов), обладающих азональными гидрохимическими характеристиками. С точки зрения экологической реабилитации территории данные водоемы не представляют серьезной проблемы, так как при ликвидации источника питания (ПСС) исчезнут в течение нескольких сезонов/лет, пройдя стадию заболоченной территории, либо могут быть ликвидированы методами технической рекультивации.

Загрязнение почв и грунтов. Выполненные почвенно-геохимические исследования позволили выявить имеющие место на изучаемой территории процессы химической трансформации почв, обусловленные поступлением загрязняющих веществ в почвенный покров и проявляющиеся в техногенном засолении почв, их загрязнении тяжелыми металлами и нефтепродуктами.
С целью исследования ПСС как источника воздействия на окружающую среду изучен солевой состав твердого осадка, оставшегося после таяния снега. Обследование проведено в 2016-2017 годах с отбором 5 проб осадка (рис. 1). Полученные результаты показали, что содержание водорастворимых веществ в верхнем горизонте (0-10 см) твердого осадка находится в следующих пределах: гидрокарбонатов - 119,6-327,1 мг/кг (среднее 228,8 мг/кг), хлоридов - 6,9-3607,4 $(274,9)$, сульфатов - 0,1-213,0 (35,9), кальция - 24,0-128,3 $(54,5)$, магния - 1,8-30,4 (10,3), натрия - 12,5-1830,0 $(181,9)$ и калия - 7,0-85,5 мг/кг (среднее 28,7 мг/кг). Из рассматриваемых веществ в наибольших количествах по сравнению с фоном находятся хлориды и натрий, коэффициенты концентраций их средних значений составляют 38 и 12 соответственно.

Значительная дифференциация в содержании водорастворимых веществ в твердом осадке ПСС обусловлена прежде всего различиями в количестве и интенсивности выпадения снега в разные годы и, соответственно, объемами применения противогололедных веществ. В результате застаивания сильноминерализованных талых вод в микропонижениях рельефа и их испарения происходит засоление почв. В растительном покрове здесь преобладают виды в наибольшей степени, приспособленные к условиям засоления.

Радиальное распределение водорастворимых веществ в почвах (почвогрунтах) в зоне влияния снеговой свалки неоднозначно на различных участках исследования. На территориях с глубоким залеганием грунтовых вод минимальное содержание водорастворимых веществ фиксируется в верхних горизонтах почв. В средней части почвенного профиля их количество увеличивается и дости- 
Содержание водорастворимых веществ в поверхностном слое (0-10 см) твердого осадка ПСС и почвах в зоне ее влияния, мг/кг

\begin{tabular}{|l|c|c|c|c|}
\hline \multirow{2}{*}{$\begin{array}{c}\text { Водорастворимые } \\
\text { вещества }\end{array}$} & \multicolumn{2}{|c|}{2016 г. } & \multicolumn{2}{c|}{2017 г. } \\
\cline { 2 - 5 } & $\frac{119,6-327,1^{*}}{228,8}$ & $\frac{110,4-163,5}{143,8}$ & $\frac{305,1-366,1}{350,9}$ & $\frac{305,1-915,3}{501,7}$ \\
\hline $\mathrm{HCO}_{3}{ }^{-}$ & $\frac{6,9-3607,4}{274,9}$ & $\frac{7,6-16,8}{10,7}$ & $\frac{17,8-212,7}{66,5}$ & $\frac{17,8-301,4}{65,0}$ \\
\hline $\mathrm{Cl}^{-}$ & $\frac{0,1-213,0}{35,9}$ & $\frac{0,1-6,8}{2,9}$ & $\frac{2,5-19,0}{7,9}$ & $\frac{3,0-42,0}{22,5}$ \\
\hline $\mathrm{SO}_{4}^{2-}$ & $\frac{24,0-128,3}{54,5}$ & $\frac{22,5-24,0}{23,5}$ & $\frac{48,1-104,2}{73,2}$ & $\frac{40,1-184,4}{83,3}$ \\
\hline $\mathrm{Ca}^{2+}$ & $\frac{1,8-30,4}{10,3}$ & $\frac{1,5-15,2}{6,7}$ & $\frac{7,3-9,8}{8,5}$ & $\frac{4,9-29,2}{11,5}$ \\
\hline $\mathrm{Mg}^{2+}$ & $\frac{12,5-1830,0}{181,9}$ & $\frac{13,3-29,5}{18,7}$ & $\frac{19,8-216,0}{88,4}$ & $\frac{5,8-176,6}{74,9}$ \\
\hline $\mathrm{Na}^{+}$ & $\frac{7,0-85,5}{28,7}$ & $\frac{4,0-6,0}{5,1}$ & $\frac{6,8-31,3}{14,9}$ & $\frac{12,3-449,0}{84,8}$ \\
\hline $\mathrm{K}^{+}$ & $\frac{171,9-6221,7}{815,0}$ & $\frac{164,8-243,2}{211,4}$ & $\frac{491,1-886,0}{610,2}$ & $\frac{520,7-1773,5}{843,7}$ \\
\hline Сумма солей & \multicolumn{3}{|c|}{} \\
\hline
\end{tabular}

*B числителе - пределы содержания, в знаменателе - средние значения.

гает максимума в нижних горизонтах. В распределении солей по почвенному профилю наблюдаются различия не только по их содержанию, но и по соотношению катионов и анионов. Для верхних горизонтов почвы характерен смешанный тип засоления, с глубины 40 см выражен хлоридный натриевый тип засоления. Почвы по степени засоления с учетом «суммарного эффекта» токсичных ионов характеризуются как среднезасоленные (значение «суммарного эффекта» 0,38-0,74 мг-экв/100 г почвы). Аналогичные результаты получены при исследовании засоления почв под снегосвалкой в Воронеже [7].

Анализ динамики содержания водорастворимых веществ (2016-2017 гг.) в твердом осадке ПСС и в почвах зоны ее воздействия показали, что их максимальное содержание в поверхностном слое (0-10 см) твердого осадка фиксировалось в 2016 году, а минимальное - в почвах прилегающей территории. Сумма солей в среднем составила 815,0 и 211,4 мг/кг соответственно (таблица 2). В 2017 году отмечалась обратная тенденция: уменьшение содержания солей в осадке ПСС и увеличение их количества в почве.

В ионном составе водных вытяжек из твердого осадка среди анионов в 2016 году доминировали гидрокарбонаты (81\%-экв), доля хлоридов составила $15 \%$-экв. Среди катионов преобладал на- трий - 51\%-экв, на кальций и калий пришлось 24 и $14 \%$-экв соответственно. По сравнению с 2016 годом в 2017 году общее содержание водорастворимых веществ в осадке уменьшилось незначительно - в 1,3 раза, поскольку сопровождалось ростом содержания гидрокарбонатов в 1,5 раза и кальция - в 1,3 раза. В то же время среднее содержание основных компонентов противогололедных смесей - хлоридов уменьшилось в 4,1 раза, натрия - в 2,1 раза, что вероятно, связано с интенсивным их выносом в нижние горизонты, сложенными преимущественно крупнозернистыми рыхлыми песками, а также атмосферными осадками в весенний и летний периоды.

В почвах в зоне влияния ПСС в 2017 году, по сравнению с 2016 годом, увеличилось содержание всех компонентов солевого состава. Такая динамика изменения концентраций макрокомпонентов свидетельствовала об усилении техногенной нагрузки со стороны «снеговой свалки» в результате растекания талых снеговых вод.

Валовое содержание тяжелых металлов в твердом осадке находилось на уровне либо ниже регионального фона (таблица 3). В почве в зоне влияния ПСС их содержание в 1,1-1,5 раза выше, чем в твердом осадке. Так, коэффициент контрастности (AР) для средних значений тяжелых металлов данных территорий составил: кадмия - 1,6, свинца - 
Содержание тяжелых металлов в поверхностном слое (0-10 см) твердого осадка «снеговой свалки» и почвы в зоне ее влияния, мг/кг

\begin{tabular}{|l|c|c|c|c|c|}
\hline \multicolumn{1}{|c|}{ Места отбора проб } & $\mathrm{Cd}$ & $\mathrm{Pb}$ & $\mathrm{Cu}$ & $\mathrm{Zn}$ & $\mathrm{Ni}$ \\
\hline $\begin{array}{l}\text { Твердый осадок ПСС } \\
\text { после таяния снега }\end{array}$ & $\frac{0,01-0,52 *}{0,24}$ & $\frac{2,7-16,8}{7,4}$ & $\frac{14,5-39,4}{22,8}$ & $\frac{23,9-39,2}{31,8}$ & $\frac{1,25-2,0}{1,6}$ \\
\hline $\begin{array}{l}\text { Почва в зоне влияния } \\
\text { ПСС }\end{array}$ & $\frac{0,15-0,83}{0,4}$ & $\frac{5,3-39,6}{14,0}$ & $\frac{6,9-44,3}{24,6}$ & $\frac{5,1-115,8}{41,3}$ & $\frac{1,5-6,9}{3,1}$ \\
\hline $\begin{array}{l}\text { Региональный фон для } \\
\text { почв, мг/кг }\end{array}$ & 0,26 & 7,3 & 33,3 & 44,7 & 6,5 \\
\hline $\begin{array}{l}\text { Среднее содержание в } \\
\text { почвах ландшафтно- } \\
\text { рекреационных зон } \\
\text { Минска** }\end{array}$ & 0,49 & 19,0 & 10,0 & 32,5 & 7,5 \\
\hline ПДК/ОДК & 0,5 & 32,0 & 33,0 & 55,0 & 20,0 \\
\hline
\end{tabular}

* В числителе - пределы содержания, в знаменателе - средние значения.

** Средние значения содержания ТМ в почвах ландшафтно-рекреационных территорий г. Минска [14].

1,9, меди $-1,1$, цинка $-1,3$ и никеля $-1,9$. Также в зоне влияния ПСС наблюдалось превышение регионального фона для максимальных значений кадмия в 3,2 раза, свинца $-2,8$, меди $-1,8$ и цинка $-2,8$ раз. Однако количество проб, в которых наблюдались превышения фона для данных элементов, не превысило $28 \%$ от общего числа отобранных образцов почв. Данная особенность свидетельствует о миграции тяжелых металлов с талыми снеговыми водами в почвы зоны влияния «снеговой свалки».

Четкой радиальной дифференциации содержания ТМ в твердом осадке ПСС не выявлено, так как в ее пределах происходило частое перемещение грунта экскаваторной техникой при проведении работ для ускорения таяния снега и выравнивания территории и накопившегося на ней твердого осадка. Вместе с тем максимальные концентрации большинства тяжелых металлов в основном приурочены к верхним насыпным техногенным грунтам (таблица 4).

Сопоставление концентрации тяжелых металлов в почве в зоне влияния ПСС с ПДК/ОДК показало, что превышение данных показателей наблюдается в единичных случаях для кадмия $-1,7$ раза, свинца $-1,2$, меди $-1,3$ и цинка - в 2,1 раза. В целом почвы в зоне влияния «снеговой свалки» по содержанию тяжелых металлов имеют низкую степень деградации.

В то же время твердый осадок ПСС и почвы в зоне ее влияния в значительной мере загрязнены нефтепродуктами. Анализ содержания нефтепродуктов в твердом осадке показал, что рассматри- ваемый объект является потенциальным загрязнителем поверхностных вод и почв. Так, среднее содержание нефтепродуктов в поверхностном горизонте (0-10 см) твердого осадка составило 2478,3 мг/кг, при диапазоне значений 743,59562,8 мг/кг.

Радиальное распределение нефтепродуктов в твердом осадке неоднозначно, что вероятно связано с перемешиванием грунта во время проведения работ по выравниванию и планированию отвала снега (точки 1 и 2) (таблица 5).

В непосредственной близости от «снеговой свалки» (точка 3) максимальное содержание нефтепродуктов наблюдается в верхнем горизонте почвы - 990,8 мг/кг и постепенно снижается до 25,1 мг/кг на глубине 80-100 см.

В зоне влияния ПСС содержание нефтепродуктов в почвах ниже и составляет в среднем 164,0 мг/кг. При этом их максимальная концентрация (397,2 мг/кг) зафиксирована на расстоянии 5 м от южной границы площадки (точка 24), минимальная (52,0 мг/кг) - в ложбине стока на расстоянии более 200 м от нее (точка 33).

Сопоставление содержания нефтепродуктов с установленным санитарно-гигиеническим нормативом (ПДК) показало, что во всех пробах твердого осадка содержание нефтепродуктов составляет от 7,4 до 95,0 ПДК, что позволяет отнести их к землям со средней степенью загрязнения (деградации).

Почвы в зоне влияния снеговой свалки с превышениями ПДК по нефтепродуктам следует отнести к категории с низкой и средней степенью деградации. 
Содержание валовых форм тяжелых металлов в твердом осадке ПСС, мг/кг

\begin{tabular}{|l|c|c|c|c|}
\hline Глубина отбора, см & $\mathrm{Cd}$ & $\mathrm{Pb}$ & $\mathrm{Cu}$ & $\mathrm{Zn}$ \\
\hline \multirow{2}{*}{$0-20$} & $\frac{0,2-1,5^{*}}{0,6}$ & $\frac{2,8-38,5}{15,2}$ & $\frac{3,3-82,9}{16,7}$ & $\frac{20,3-115,7}{54,2}$ \\
\hline \multirow{2}{*}{$20-30$} & $\frac{0,2-0,6}{0,4}$ & $\frac{9,6-36,1}{20,0}$ & $\frac{8,6-34,5}{20,6}$ & $\frac{19,7-66,3}{38,2}$ \\
\hline \multirow{2}{*}{$40-60$} & $\frac{0,2-0,5}{0,3}$ & $\frac{9,4-17,4}{13,3}$ & $\frac{6,4-18,3}{11,8}$ & $\frac{10,6-20,1}{13,9}$ \\
\hline ПДК/ОДК & 0,5 & 32,0 & 33,0 & 55,0 \\
\hline
\end{tabular}

* В числителе - пределы содержания, в знаменателе - средние значения.

Состояние растительного покрова. Трансформация растительного покрова в районе размещения ПСС связана с техногенным изменением рельефа, почвенного покрова и гидрологического режима территории, возникших в результате разнофакторных воздействий, характерных для неблагоустроенных ландшафтно-рекреационных территорий города [4].

Наибольшей техногенной трансформации подвержен растительный покров в месте размещения ПСС и в зоне ее воздействия.

Древесная растительность ранее существовавших посадок питомника в непосредственной близости от западной границы ПСС к настоящему время засохла и погребена под отвалами техногенных отложений, остатки которой представлены засыхающими деревьями осины, березы повислой, клена ясенелистного, ольхи черной, кустарников ивы. В целом, около 0,4 га древостоев участка питомника, расположенных в зоне затопления «засоленными снеговыми водами», погибли.

На техногенных отложениях растительный покров полностью уничтожается при размещении загрязненного снега с городских территорий. За летний период твердый осадок ПСС (мелкий песок с включением строительного мусора, отходов дорожного покрытия) зарастает видами первопоселенцами (эксплерентами) с невысоким проективным покрытием (до 40\%). В разреженном покрове встречаются спорыш лежачий и птичий, полынь обыкновенная, мать-и-мачеха, лапчатка гусиная, пырей ползучий, лебеда развесистая, одуванчик лекарственный, щавель топяной, золотарник канадский и другие виды. На локальных участках в зоне воздействия ПСС с высоким содержанием солей в поверхностном слое почвы проективное покрытие травами составляет 10-15\%. Из произрастающих здесь видов следует отметить полынь обыкновенную, пырей ползучий, марь белую, лебеду развесистую, мать-и-мачеху, лапчатку гусиную.

В зоне подтопления талыми водами с ПСС вблизи ее бортов на избыточно увлажненных и обводненных участках временного водоема сформировались сообщества рогоза широколистного, тростника обыкновенного, с участием щавеля топяного, осок, изредка встречаются - чесночница черешчатая, частуха подорожниковая, единично белокрыльник болотный.

Следует обратить внимание, что во временном водоеме, где получила развитие типичная водноболотная растительность, в июле 2017 года отмечены выводки кряквы с 5 птенцами и лысухи - с 3 птенцами.

В процессе восстановления растительного покрова на территориях, подвергшихся техногенному нарушению, в том числе в местах техногенных наносов «снеговой свалки», растительный покров проходит несколько стадий развития.

1. Инициальная (внедрение растений первопоселенцев). Для данной стадии на участках со свежими техногенными отложениями характерны: низкое проективное покрытие растениями субстрата (10-30\%), случайные комбинации видов с преобладанием одно-, двухлетних растений; высокая контрастность экобиоморного состава, преобладание в фитоценозах видов эксплерентов-анемохоров и побегообразующих, слабая выраженность структуры сообществ (отсутствие выраженного доминирования и эдификаторов), высокая динамичность во времени состава фитоценозов. В растительном покрове при обследовании нарушенных почв и отвалов техногенных грунтов встречены отдельные куртины пырея ползучего, полевицы побегообразующей, одуванчика лекарственного, мать-и-мачехи обыкновенной, пижмы обыкновен- 
Радиальное распределение нефтепродуктов в твердом осадке ПСС и в почве в зоне ее влияния

\begin{tabular}{|l|c|c|}
\hline \multirow{2}{*}{ Место и точка отбора } & $\begin{array}{c}\text { Глубина отбора, } \\
\text { см }\end{array}$ & $\begin{array}{c}\text { Содержание нефтепродуктов, } \\
\text { мг/кг }\end{array}$ \\
\hline \multirow{3}{*}{ Площадка складирования снега, т. 1 } & $0-10$ & 449,9 \\
\cline { 2 - 3 } & $20-40$ & 496,3 \\
\cline { 2 - 3 } & $60-80$ & 980,0 \\
\hline \multirow{4}{*}{ Площадка складирования снега, т.2 } & $0-10$ & 131,6 \\
\cline { 2 - 3 } & $20-40$ & 557,5 \\
\cline { 2 - 3 } & $40-60$ & 279,3 \\
\hline \multirow{4}{*}{$\begin{array}{l}\text { Почва в зоне влияния площадки } \\
\text { складирования снега, т. 3 }\end{array}$} & $60-80$ & 231,1 \\
\cline { 2 - 3 } & $100-120$ & 318,7 \\
\cline { 2 - 3 } & $0-20$ & 990,8 \\
\cline { 2 - 3 } & $20-35$ & 942,1 \\
\cline { 2 - 3 } & $35-40$ & 348,4 \\
\hline
\end{tabular}

ной, полыни, мари белой, лебеды раскидистой, лапчатки гусиной, клевера ползучего, спорыша лежачего.

2. Переходная стадия. Она идентифицируется на более старых наносах. Отличаетсяболее высоким проективным покрытием, преобладанием в покрове преимущественно многолетних бобовых растений, с участием полыней и злаков. Проективное покрытие на таких участках достигает 70-80\%. Травянистый покров представлен широким спектром видов, где доминируют клеверы (пашенный, ползучий и луговой), часто встречаются полынь горькая и полевая, одуванчик лекарственный, бодяк полевой, сумочник обыкновенный (пастушья сумка), лебеда раскидистая, репейник большой, золотарник канадский, тысячелистник обыкновенный, донник белый и др. Из злаков произрастают ежа сборная, овсяницы, полевицы, мятлик однолетний, спорыш птичий (вблизи троп).

На турбированных почвогрунтах в 20 м от западного борта ПСС растительность представлена травяными сообществами залежей и нарушенных земель инициальных стадий развития (проективное покрытие - 40-50\%). В напочвенном покрове встречаются пырей ползучий, клевер ползучий и луговой, овсяница красная, лапчатка гусиная, ежа сборная, вейник наземный, золотарник канадский, полыни горькая и полевая, лебеда развесистая, мать-и-мачеха, бодяк полевой, лютики едкий и ползучий, которые образуют куртины, перемежающиеся с обнаженной почвой и строительными отходами. Изредка встречаются беглецы из культуры - подсолнечник клубненосный (топинамбур), хрен обыкновенный, свидетельствующие об использовании ранее данного участка под огороды. На участке отмечены отдельные куртины борщевика Сосновского. Доля участия рудеральных видов в растительном покрове данного участка диагностируется как очень высокая, проективное покрытие травянистого яруса низкое, что позволяет отнести растительность участка к деградированной.

В течение весеннего и летнего периодов на участке потока талых вод со «снеговой свалки» на скальпированных почвах, перерытых песчаными наносами, развивается растительность инициальных стадий зарастания нарушенных земель. Она представлена пыреем ползучим, клевером ползучим, полевицей побегообразующей, одуванчиком лекарственным, мать-и-мачехой обыкновенной, полынью обыкновенной, лапчаткой гусиной и другими видами.

Все близлежащие к зоне воздействия ПСС территории имеют либо более возвышенное положение в рельефе по отношению к ПСС и основным потокам талых вод с нее, либо ограждены от их воздействия естественными склонами и техногенными отложениями, что предотвратило влияние на почвенно-растительный покров талых вод и наносов со снеговой свалки.

\section{ВЫВОДЫ}

Рассматриваемая площадка временного складирования снега занимает элювильно-аккумулятивное положение в системе сопряженных элементарных ландшафтов. Таким образом, ее воздействие экранировано на прилегающие территории, 
новообразованным элювиальным и трансэлювиальным ландшафтами (западная и восточная части исследуемого участка). Загрязняющее влияние ПСС, кроме территорий, непосредственно к ней примыкающих, распространяется согласно потоку талых вод в юго-восточном направлении, оказывая загрязняющее воздействие на почвы соподчиненных элементарных ландшафтов (транссупераквальных и супераквальных).

Как источник воздействия на окружающую среду ПСС может рассматриваться как временная техногенная геохимическая аномалия с повышенным содержанием в твердом осадке хлоридов и натрия, коэффициенты концентраций средних значений которых составляют 38 и 12 соответственно. Высокие концентрации нефтепродуктов (743,59562,8 мг/кг) в период снеготаяния обнаруживаются в воде поверхностного стока.

Функционирование ПСС сопряжено с формированием временных водотоков и водоемов в зоне ее влияния, последние при определенных условиях могут устойчиво функционировать как самостоятельные водные экосистемы, обладающие азональными гидрохимическими характеристиками (хлоридный натриевый, гидрокарбонатно-хлоридный натриевый и хлоридно-гидрокарбонатный кальциево-натриевый типы). Вероятнее всего, при ликвидации источника питания данные водоемы исчезнут в течение нескольких сезонов/лет, пройдя стадию заболоченной территории, или могут быть ликвидированы методами технической рекультивации.

В результате застаивания минерализованных талых вод в микропонижениях рельефа и их испарения происходит засоление почв, что идентифицируется растительным покровом, в котором преобладают виды в наибольшей степени, приспособленные к условиям засоления.

Содержания нефтепродуктов во всех пробах твердого осадка (от 7,4 до 95,0 ПДК для почв) позволяет отнести их к землям со средней степенью загрязнения (деградации). Почвы в зоне влияния снеговой свалки с превышениями ПДК по нефтепродуктам следует отнести к категории с низкой и средней степенью деградации.

Трансформация растительного покрова на ПСС и в зоне ее воздействия во многом определяется воздействием техногенных отложений «снеговой свалки», загрязнением водных потоков и почвогрунтов. Наибольшей трансформации подверглась растительность на площадке складирования снега, а также на участках подтопления или засоле- ние почв, что привело к усыханию древесно-кустарниковой растительности бывшего питомника. Для этой территории характерно ежегодное уничтожение растительности наносами со свалки и сезонное развитие редкого покрова рудеральных видов. Лесные сообщества (дубрава и ельник), посадки питомника, приуроченные к холмистоволнистым урочищам, расположены выше зоны воздействия стока с ПСС. Признаки деградации растительного покрова в данных растительных комплексах, вызванные функционированием ПСС не выявлены.

\section{СПИСОК ЛИТЕРАТУРЫ}

1. Алекин О. А. Основы гидрохимии / О. А. Алекин. - Ленинград : Гидрометеоиздат, 1970. - 442 с.

2. Выработанные торфяники в городах: опыт ландшафтных исследований / Т. И. Кухарчик [и др.] // Природные ресурсы. - 1999. - № 2. - С. 8391.

3. Генеральный план г. Минска. - URL: http:// minsk.gov.by/share/2010/04/08/data/20161012.gp.jpg (дата обращения: 17.10.2017).

4. Городская среда: геоэкологические аспекты / В. С. Хомич [и др.]. - Минск : Белорусская наука, 2013. $-301 \mathrm{c}$.

5. Ландшафтные воды в условиях техногенеза / О. В. Кадацкая [и др.]. - Минск : Белорусская наука, 2005. - 347 c.

6. Об установлении нормативов качества воды поверхностных водных объектов : постановление Министерства природных ресурсов и охраны окружающей среды Республики Беларусь № 13 от 30 марта 2015 г. URL: http://www.pravo.by/upload/docs/op/W21529808 1429909200.pdf (дата обращения: 17.10.2017).

7. Прожорина Т. И. Исследование влияния снегосвалки на почвенный покров прилегающей территории (на примере города Воронежа) / Т. И. Прожорина, О. В. Крутова // Вестник Воронежского государственного университета. Сер. География. Геоэкология. -2019. - № 2. - С. 77-81.

8. РД 52.04.186-89 Руководство по контролю загрязнения атмосферы. - Ленинград, 1991. - 693 с.

9. Состояние природной среды Беларуси: экологический бюллетень, 2013 год / под ред. В. Ф. Логинова. - Минск, 2014. - 364 с.

10. ТКП 17.06-09-2013 (02120) Охрана окружающей среды и природопользование. Гидросфера. Требования к размещению и эксплуатации площадок складирования снега. - Введ. 01.10.13. - Минск : Минприроды, 2013. -8 с.

11. ТКП 17.03-03-2014 (02120) Охрана окружающей среды и природопользование. Земли. Правила и порядок работ (услуг) по обращению с загрязненными землями (включая почвы). - Введ. 01.01.15. - Минск : Минприроды, 2015. - 16 с. 
12. ТКП 17.13-15-2014 (02120) Охрана окружающей среды и природопользование. Аналитический (лабораторный) контроль. Порядок отбора проб атмосферного воздуха, атмосферных осадков и снежного покрова для определения концентраций загрязняющих веществ и метеорологические наблюдения. - Введ. 01.03.15. - Минск : Минприроды, 2015. - 16 с.

13. Хайрулина Е. А. Геоэкологические проблемы разработки месторождений калийных солей / Е. А. Хайрулина, В. С. Хомич, М. Ю. Лискова // Известия Тульского университета. Науки о Земле. - 2018. - Вып. 2. C. 112-126.

14. Хомич В. С. Экогеохимия городских ландшафтов Беларуси / В. С. Хомич, С. В. Какарека, Т. И. Кухарчик. - Минск : РУП Минсктиппроект, 2004. - 260 с.

15. Экогеохимия городских ландшафтов / под ред. Н. С. Касимова. - Москва : Издательство Московского университета, 1995. - 336 с.

\section{REFERENCES}

1. Alekin O. A. Osnovy gidrokhimii / O. A. Alekin. Leningrad : Gidrometeoizdat, 1970. - 442 s.

2. Vyrabotannye torfyaniki v gorodakh: opyt landshaftnykh issledovaniy / T. I. Kukharchik [i dr.] // Prirodnye resursy. -1999 . - № 2. - S. 83-91.

3. General'nyy plan g. Minska. - URL: http:// minsk.gov.by/share/2010/04/08/data/20161012.gp.jpg (data obrashcheniya: 17.10.2017).

4. Gorodskaya sreda: geoekologicheskie aspekty / V. S. Khomich [i dr.]. - Minsk : Belorusskaya nauka, 2013. $-301 \mathrm{~s}$.

5. Landshaftnye vody $\mathrm{v}$ usloviyakh tekhnogeneza / O. V. Kadatskaya [i dr.]. - Minsk : Belorusskaya nauka, 2005. - $347 \mathrm{~s}$.

6. Ob ustanovlenii normativov kachestva vody poverkhnostnykh vodnykh ob"ektov : postanovlenie Ministerstva prirodnykh resursov i okhrany okruzhayushchey sredy Respubliki Belarus' № 13 ot 30 marta 2015 g. - URL: http:/

\section{Хомич Валерий Степанович}

доктор географических наук, заместитель директора по научной работе Института природопользования Национальной академии наук Беларуси, г. Минск, т. (+375) 1726724 19, E-mail: valery_khomich@ @ail.ru

\section{Кравчук Людмила Александровна}

кандидат географических наук, ведущий научный сотрудник лаборатории оптимизации геосистем Института природопользования Национальной академии наук Беларуси, г. Минск, т. (+375) 1726750 75, E-mail: kravchu-k@yandex.by

Кадацкая Ольга Владимировна

кандидат географических наук, старший научный сотрудник лаборатории оптимизации геосистем Института природопользования Национальной академии
/www.pravo.by/upload/docs/op/W21529808_1429909200. pdf (data obrashcheniya: 17.10.2017).

7. Prozhorina T. I. Issledovanie vliyaniya snegosvalki na pochvennyy pokrov prilegayushchey territorii (na primere goroda Voronezha) / T. I. Prozhorina, O.V. Krutova // Vestnik Voronezhskogo gosudarstvennogo universiteta. Ser. Geografiya. Geoekologiya. - 2019. - № 2. - S. 77-81.

8. RD 52.04.186-89 Rukovodstvo po kontrolyu zagryazneniya atmosfery. - Leningrad, 1991. - $693 \mathrm{~s}$.

9. Sostoyanie prirodnoy sredy Belarusi: ekologicheskiy byulleten', 2013 god / pod red. V. F. Loginova. - Minsk, 2014. - $364 \mathrm{~s}$.

10. TKP 17.06-09-2013 (02120) Okhrana okruzhayushchey sredy i prirodopol'zovanie. Gidrosfera. Trebovaniya k razmeshcheniyu i ekspluatatsii ploshchadok skladirovaniya snega. - Vved. 01.10.13. - Minsk : Minprirody, 2013. - 8 s.

11. TKP 17.03-03-2014 (02120) Okhrana okruzhayushchey sredy i prirodopol'zovanie. Zemli. Pravila i poryadok rabot (uslug) po obrashcheniyu s zagryaznennymi zemlyami (vklyuchaya pochvy). - Vved. 01.01.15. - Minsk : Minprirody, 2015. - $16 \mathrm{~s}$.

12. TKP 17.13-15-2014 (02120) Okhrana okruzhayushchey sredy i prirodopol'zovanie. Analiticheskiy (laboratornyy) kontrol'. Poryadok otbora prob atmosfernogo vozdukha, atmosfernykh osadkov i snezhnogo pokrova dlya opredeleniya kontsentratsiy zagryaznyayushchikh veshchestv i meteorologicheskie nablyudeniya. - Vved. 01.03.15. - Minsk : Minprirody, 2015. - 16 s.

13. Khayrulina E. A. Geoekologicheskie problemy razrabotki mestorozhdeniy kaliynykh soley / E. A. Khayrulina, V. S. Khomich, M. Yu. Liskova // Izvestiya Tul'skogo universiteta. Nauki o Zemle. - 2018. - Vyp. 2. - S. 112-126.

14. Khomich V. S. Ekogeokhimiya gorodskikh landshaftov Belarusi / V. S. Khomich, S. V. Kakareka, T. I. Kukharchik. - Minsk : RUP Minsktipproekt, 2004. $260 \mathrm{c}$.

15. Ekogeokhimiya gorodskikh landshaftov / pod red. N. S. Kasimova. - Moskva : Izdatel'stvo Moskovskogo universiteta, 1995. - $336 \mathrm{~s}$.

\section{Khomich Valery Stepanovich}

Doctor of Geographical Sciences, Deputy Director for Science of the State Scientific Institution «Institute for Environmental Management National Academy of Sciences of Belarus», Minsk, tel. (+375) 1726724 19, E-mail: valery khomich@mail.ru

Kravchuk Liudmila Alexandrovna

Candidate of Geographical Sciences, Leading Researcher of the Laboratory of Geosystem Optimization of the State Scientific Institution «Institute for Environmental Management National Academy of Sciences of Belarus», Minsk, tel. (+375) 1726750 75, E-mail: kravchu-k@yandex.by

Kadatskaya Olga Vladimirovna

Candidate of Geographical Sciences, Senior Researcher of the Laboratory of Geosystem Optimization of the State Scientific Institution «Institute for Environmental Manage- 
наук Беларуси, г. Минск, т. (+375) 1726714 10, E-mail: olga-kad@rambler.ru

Санец Елена Васильевна

кандидат географических наук, заведующий лаборатории оптимизации геосистем Института природопользования Национальной академии наук Беларуси, г. Минск, т. (+375) 1726804 52, E-mail: elena-sanets@yandex.by

\section{Овчарова Елена Петровна}

кандидат географических наук, научный сотрудник лаборатории оптимизации геосистем Института природопользования Национальной академии наук Беларуси, г. Минск, т. (+375) 1726714 10, E-mail: geosystem1@rambler.ru

\section{Рыжиков Владимир Анатольевич}

кандидат географических наук, старший научный сотрудник лаборатории оптимизации геосистем Института природопользования Национальной академии наук Беларуси, г. Минск, т. (+375) 1726633 66, E-mail: ryghik24@tut.by

Баженова Наталья Михайловна научный сотрудник лаборатории оптимизации геосистем Института природопользования Национальной академии наук Беларуси, г. Минск, т. (+375) 1726750 75, E-mail: nata.bazh@mail.ru ment National Academy of Sciences of Belarus», Minsk, tel. (+375) 1726714 10, E-mail: olga-kad@ @ambler.ru

Sanets Elena Vasil'evna

Candidate of Geographical Sciences, Head of the Laboratory of Geosystem Optimization of the State Scientific Institution «Institute for Environmental Management National Academy of Sciences of Belarus», Minsk, tel. (+375) 1726804 52, E-mail: elena-sanets@yandex.by Aucharova Alena Pjatrouna

Candidate of Geographical Sciences, Researcher of the Laboratory of Geosystem Optimization of the State Scientific Institution «Institute for Environmental Management National Academy of Sciences of Belarus», Minsk, tel. (+375) 1726714 10, E-mail: geosystem1 @ rambler.ru Ryzikov Vladimir Anatol'evich

Candidate of Geographical Sciences, Senior Researcher of the Laboratory of Geosystem Optimization of the State Scientific Institution «Institute for Environmental Management National Academy of Sciences of Belarus», Minsk, tel. (+375) 1726633 66, E-mail: ryghik24@tut.by

Bazhenava Natallia Mikhajlauna

Researcher of the Laboratory of Geosystem Optimization of the State Scientific Institution «Institute for Environmental Management National Academy of Sciences of Belarus», Minsk, tel. (+375) 1726750 75, E-mail: nata.bazh@mail.ru 